\title{
PENERAPAN KONSEP K3 DALAM MENINGKATKAN KUALITAS KESEHATAN DI LINGKUNGAN RUMAH SAKIT
}

\author{
Kristina N Tampubolon \\ kristinatampubolon381@gmail.com
}

\begin{abstract}
ABSTRAK
Kesehatan kerja merupakan masalah setiap individu karena bekerja dibutuhkan semua orang sebagai sumber pendapatan untuk memenuhi kebutuhan hidup.Sejak lama diketahui bahwa bekerja dapat menyebabkan gangguan kesehatan atau penyakit. Sebaliknya, kesehatan dapat mengganggu pekerjaan. Artikel ini bertujuan memberikan pemahaman tentang konsep, praktik dan manfaat kesehatan kerja bagi para pekerja dan pemberi kerja. Kesehatan kerja seharusnya tidak hanya terfokus pada diagnosis dan pengobatan klinis, tetapi juga mengerjakan rekognisi hazard, penilaian risiko dan intervensi untuk menghilangkan atau meminimalkan risiko. Lingkupnya diperluas untuk mencegah penyakit dengan cara: (1) penempatan pekerja pada pekerjaan/jabatan yangsesuai (fit) dengan status kesehatan dan kapasitas kerjanya. (2) program promosi kesehatan pekerja; (3) perbaikan lingkungan kerja; (4) perbaikan peker-jaan; (5) pengembangan pengorganisasian pekerjaan dan budaya bekerja.; dan (6) surveilans kesehatan pekerja.Tingkat keselamatan dan kesehatan kerja (K3) karyawan sangat dibutuhkan ketika karyawan melakukan aktivitas kerja. Terutama bagi karyawan yang bekerja di lingkungan kerja yang memiliki risiko keselamatan dan kesehatan yang tinggi, karena keselamatan kerja di rumahsakit tidak hanya ditimbulkan oleh sistem yang telah diterapkan oleh rumah sakit tetapi juga kesadaran setiap individu untuk menghindari kecelakaan kerja.
\end{abstract}

Kata kunci : Konsep dasar K3RS, Kesehatan Kerja, Risiko dan Hazard dalam asuhan keperawatan. 


\section{A. LATAR BELAKANG}

Penyebab dari kecelakaan kerja bisa datang kapan, di mana dan kepada siapa saja, terhadap yang beresiko mengalami kecelakaan kerja yang ditimbulkan karena faktor kesengajaan atau tidak. Dari sebuahModul tentang Keselamatan dan Kesehatan Kerja di Tempat Kerja bahwa,potensi bahaya keselamatan dan kesehatan kerja dapat di mana dan kepada siapa saja.Resiko bisa berakibat fatal atau hanya kecelakaan kecil, tergantung pada tingkat peluang bahaya yang ada.Penyebab dari gangguan kesehatan dan keselamatan kerja dikarenakan suatu bahaya kesehatan akan muncul apabila seseorang kontak dengan sesuatu yang dapat menyebabkan gangguan atau kerusakan bagi tubuh ketika terjadi pekerjaan yang berlebih.

Bahaya kesehatan dapat menyebabkan penyakit yang disebabkan oleh pekerjaan suatu sumber bahaya di tempat kerja. Potensi bahaya kesehatan biasanya berasal dari lingkungan kerja diantaranya faktor kimia, faktor fisik,faktor biologi, faktor ergonomis, dan faktor psikologi. Maka dari itu Keselamatan dan Kesehatan Kerja sangat penting untuk kepentingan diri sendiri dan lingkungan tempat kita bekerja.

Keselamatan dan Kesehatan Kerja (K3)adalah suatu program yang dibuat pekerja maupun pengusaha sebagai upaya mencegah timbulnya kecelakaan dan penyakit akibat kerja,dengan cara mengenali hal-hal yang berpotensi menimbulkan kecelakaan dan penyakit akibat kerja serta tindakan antisipatif apabila terjadi kecelakaan dan penyakit akibat kerja. Tujuan dari dibuatnya program K3 adalah untuk mengurangi biaya perusahaan apabila timbul kecelakaan dan penyakit akibat kerja.Untuk meminimalisir angka kecelakaan kerja atau menghilangkan angka kecelakan kerja perlu dilakukan sebuah langkah antisipasi baik dari pihak pekerja maupun pihak manajemen perusahaan.

Kesadaran karyawan terhadapKeselamatan dan Kesehatan Kerja ditunjukkan dengan Sikap Profesionalyang dibutuhkan oleh perusahaan, sesuai dengan penelitian.Sikap Profesioanal karyawan ditunjukkan dengan menjalankan prosedur K3 dan kesadaran yang ditanamkan sejak pembelajaran Mahasiswa di Laboratorium. Kesadaran terhadap K3 ini akan meminimalkan resiko kecelakaan dirumah sakit. 


\section{B. METODE}

Dalam karya ilmiah ini penulis menggunakan metode kepustakaan dengan cara membaca berbagai sumber seperti : buku,ebook,jurnal,karya ilmiah,dan sumber lainnya yang dapat dipercaya dikarenakan agar setiap pembaca tidak dipusingkan dengan artikelartikel yang kurang efektif dan belum dianalisis kebenarannya.Sumber-sumber yang dibaca dan dicari penulis juga berkenaan dengan materi permasalahan yang akan dibahas oleh penulis sehingga sistematis yang dibahas selalu berhubungan dan dapat mempermudah pemahaman pembaca.

\section{HASIL}

Keselamatan dan kesehatan kerja (k3) difilosofikan sebagai suatu pemikiran dan upaya untuk menjamin keutuhan dan kesempurnaan baik jasmani maupun rohani tenaga kerja pada khususnya dan manusia pada umumnya, hasil karya dan budayanya menuju masyarakat makmur dan sejahtera. Sedangkan pengertian secara keilmuan adalah suatu ilmu pengetahuan dan penerapannya dalam usaha mencegah kemungkinan terjadinya kecelakaan dan penyakit akibat kerja. Kesehatan dan keselamatan Kerja (K3) tidak dapat dipisahkan dengan proses produksi baik jasa maupun industri.

Keselamatan Kerja adalah keselamatan yang bertalian dengan mesin, pesawat, alat kerja, bahan, dan proses pengolahannya, landasan tempat kerja dan lingkungannya serta cara-cara melakukan pekerjaan. Keselamatan Kerja memiliki sifat sebagai berikut.

a. Sasarannya adalah lingkungan kerja.

b. Bersifat teknik.

Pengistilahan Keselamatan dan Kesehatan Kerja bermacam-macam, ada yang menyebutnya Hygene Perusahaan dan Kesehatan Kerja (Hyperkes) dan ada yang hanya disingkat K3, dan dalam istilah asing dikenal Occupational Safety and Health. 
Pengertian sehat senantiasa digambarkan sebagai suatu kondisi fisik, mental dan sosial seseorang yang tidak saja bebas dari penyakit atau gangguan kesehatan melainkan juga menunjukkan kemampuan untuk berinteraksidengan lingkungan dan pekerjaannya. Paradigma baru dalam aspek kesehatan mengupayakan agar yang sehat tetap sehat dan bukan sekadar mengobati, merawat,atau menyembuhkan gangguan kesehatan atau penyakit. Oleh karenanya, perhatian utama di bidang kesehatan lebih ditujukan ke arah pencegahan terhadap kemungkinan timbulnya penyakit serta pemeliharaan kesehatan seoptimal mungkin. Status kesehatan seseorang ditentukan oleh empat faktor sebagai berikut.

A. Lingkungan, berupa lingkungan fisik (alami, buatan), kimia (organik/anorganik, logam berat, debu), biologik (virus, bakteri, mikroorganisme), dan sosial budaya (ekonomi, pendidikan, pekerjaan).

B. Perilaku yang meliputi sikap, kebiasaan, tingkah laku.

C. Pelayanan kesehatan: promotif, perawatan, pengobatan, pencegahan kecacatan, rehabilitasi.

D. Genetik, yang merupakan faktor bawaan setiap manusia

\section{E. PEMBAHASAN}

K3RS (Keselamatan dan Kesehatan Kerja Rumah Sakit) adalah segala kegiatan untuk menjamin dan melindungi keselamatan dan kesehatan bagi sumber daya manusia rumah sakit, pasien, pendamping pasien, pengunjung, maupun lingkungan rumah sakit melalui upaya pencegahan kecelakan kerja dan penyakit akibat kerja di rumah sakit.

Keselamatan Kerja adalah pengetahuan tentang upaya yang dilakukan untuk pencegahan kecelakaan kerja, kerusakan dan segala bentuk kerugian baik terhadap manusia, maupun yang berhubungan dengan penggunaan mesin, pesawat, alat, bahan dan proses pengolahannya, lingkungan tempat kerja serta aktivitas dalam melakukan pekerjaan.

Definisi kesehatan kerja mengacu pada Komisi Gabungan ILO/WHO dalam kesehatan kerja pada tahun 1950 yang disempurnakan pada tahun 1995 adalah upaya mempertahankan dan meningkatkan derajat kesehatan fisik, mental dan kesejahteraan sosial semua pekerja yang setinggi-tingginya. 
Mencegah gangguan kesehatan yang disebabkan oleh kondisi pekerjaan, melindungi pekerja dari faktor risiko pekerjaan yang merugikan kesehatan, penempatan dan pemeliharaan pekerja dalam suatu lingkungan kerja disesuaikan dengan kapabilitas fisiologi dan psikologinya serta disimpulkan sebagai adaptasi pekerjaan kepada manusia dan setiap manusia kepada pekerjaannya.

Kecelakaan yaitu suatu kejadian yang tidak diinginkan yang menimbulkan kerugian pada manusia (menyebabkan orang cedera), kerusakan properti, lingkungan ataupun kegiatan proses kerja, sebagai akibat dari kontrak dengan sumber energi seperti mekanis, kimia, kinetik dan fisik yang melebihi batas kemampuan tubuh, alat atau struktur.

Dalam jurnal ini akan membahas tentang konsep K3 di lingkungan Rumah Sakit.Konsep dasar K3 antara lain sebagai berikut :

\section{Konsep sehat dan Kesehatan Kerja}

Pengertian sehat senantiasa digambarkan sebagai suatu kondisi fisik, mental dan sosial seseorang yang tidak saja bebas dari penyakit atau gangguan kesehatan melainkan juga menunjukkan kemampuan untuk berinteraksidengan lingkungan dan pekerjaannya. Sehat merupakan hak azazi manusia.

Definisi kesehatan kerja adalah spesialisasi dalam ilmu kesehatan/kedokteran beserta praktiknya yang bertujuan agar pekerja/masyarakat pekerja beserta memperoleh derajat kesehatan yang setinggi-tingginya, baik fisik atau mental, maupun sosial dengan usaha-usaha preventif dan kuratif, terhadap penyakit-penyakit/gangguan-gangguan kesehatan yang diakibatkan faktor-faktor pekerjaan dan lingkungan kerja, serta terhadap penyakit-penyakit umum. Konsep kesehatan kerja dewasa ini semakin berubah, bukan sekadar "kesehatan pada sektor industri" saja melainkan juga mengarah kepada upaya kesehatan untuk semua orang dalam melakukan pekerjaannya (total health of all at work). Keselamatan kerja sama dengan hygeneperusahaan. Kesehatan kerja memiliki sifat sebagai berikut.

a. Sasarannya adalah manusia.

b. Bersifat medis. 


\section{Risiko \& Hazard Dalam Pemberian Asuhan Keperawatan}

\section{a) RISIKO}

Risiko adalah gabungan dari kemungkinan (frekuensi) dan akibat atau konsekuensi dari terjadinya bahaya tersebut. Penilaian risiko adalah penilaian menyeluruh untuk mengidentifikasi bahaya dan menentukan apakah risiko dapat diterima. Manajemen risiko adalah pengelolaan risiko yang mencakup identifikasi, penilaian dan pengendalian risiko. Manajemen risiko terdiri dari 3 langkah pelaksanaan yaitu identifikasi bahaya, penilaian risiko dan pengendalian risiko.

Identifikasi risiko merupakan suatu proses yang secara sistematis dan terus menerus dilakukan untuk mengidentifikasi kemungkinan timbulnya risiko atau kerugian terhadap kekayaan, hutang, dan personil Rumahsakit. Proses identifikasi harus dilakukan secara cermat dan komprehensif, sehingga tidak ada risiko yang terlewatkan atau tidak teridentifikasi. Dalam pelaksanaannya, identifikasi risiko dapat dilakukan dengan beberapa teknik, antara lain brainstorming, questionnaire, industry benchmarking, scenario analysis, risk assessment workshop, incident investigation.

Penilaian risiko adalah proses untuk menentukan pengendalian terhadap tingkat risiko kecelakaan kerja/ penyakit akibat kerja. Penilaian risiko adalah proses evaluasi risiko-risiko yang diakibatkan adanya bahaya-bahaya, dengan memperhatikan kecukupan pengendalian yang dimiliki, dan menentukan apakah risikonya dapat diterima atau tidak.

Pengendalian risiko terhadap bahaya yang teridentifikasi dilakukan setelah dilakukan penilaian sebelumnya, sehingga pengendalian risiko bahaya diprioritaskan pada bahaya dengan kategori paling tinggi ke rendah.Pengendalian risiko pada kategori High dapat dilakukan dengan mengurangi risiko bahaya serendah mungkin sehingga risiko bahaya dapat diterima. Pengendalian pada tingkat ini dilakukan dengan kontrol dari teknisi serta isolasi terhadap sumber bahaya. Risiko bahaya pada kategori Moderate, dimana risiko bahaya pada kategori ini dapat ditoleransi.

Pengendalian risiko pada kategori Moderate dapat dilakukan dengan mengatur manajemen, misalnya degan program berupa tindakan dan referensi dari HSE (Health Safety Executive), JSEA (Job Safety Environment Analysis). Risiko bahaya kategori Low yaitu kategori bahaya paling rendah dan dapat ditoleransi. 
Pengendalian risiko pada kategori ini dapat dilakukan dengan manajemen risiko harian maupun dengan referensi JSEA (Job Safety Environment Analysis).

Hazard adalah faktor faktor intrinsik yang melekat pada sesuatu berupa barang atau kondisi dan mempunyai potensi menimbulkan efek kesehatan maupun keselamatan pekerja serta lingkungan yang memberikan dampak buruk. Faktor Bahaya Biologi (Seperti : Jamur, Virus, Bakteri, dll.), Faktor Bahaya Kimia (Seperti: Gas, Debu, Bahan Beracun, dll.), Faktor Bahaya Fisik/Mekanik (Seperti : Mesin, Tekanan, dll.), Faktor Bahaya Biomekanik (Seperti: Posisi Kerja, Gerakan, dll.), Faktor Bahaya Sosial Psikologis (Seperti : Stress, Kekerasan, dll.).

Bahaya secara luas diklasifikasikan sebagai biologis dan nonbiologis. Tanggapantanggapan ini disortir untuk menghasilkan klasifikasi gabungan, biologis atau nonbiologis antara lain adalah :

- Bahaya biologis didefinisikan untuk dimasukkan luka/ luka/ laserasi, luka terkait yang tajam, kontak langsung dengan spesimen yang terkontaminasi/ bahan biohazardous, bioterorisme, yang ditularkan melalui darah patogen, penyakit infeksi/ infeksi, penyakit udara, penyakit vektor yang ditanggung, dan kontaminasi silang dari material kotor;

* Bahaya nonbiologis didefinisikan untuk termasuk fisik, psikososial, dan ergonomis bahaya :

$\checkmark$ Bahaya fisik termasuk slip, perjalanan, jatuh, luka bakar, fraktur, radiasi dari sinarX, kebisingan, dan radiasi nonionisasi;

$\checkmark$ Bahaya psikososial termasuk fisik, penyalahgunaan psikososial, seksual, dan verbal dan menekankan;

$\checkmark$ Bahaya ergonomis adalah muskuloskeletal cedera seperti nyeri otot/ strain/ terkilir. Identifikasi bahaya merupakan langkah awal dalam mengembangkan manajemen risiko $\mathrm{K} 3$.

Mengidentifikasi suatu bahaya adalah upaya sistematis untuk mengetahui potensi bahaya yang ada di lingkunga kerja. Dengan mengetahui sifat dan karakteristik bahaya, maka dapat lebih berhati-hati dan waspada untuk melakukan langkah-langkah pengamanan agar tidak terjadi kecelakaan,namun tidak semua bahaya dapat dikenali dengan mudah. 


\section{F. PENUTUP}

K3RS (Keselamatan dan Kesehatan Kerja Rumah Sakit) adalah segala kegiatan untuk menjamin dan melindungi keselamatan dan kesehatan bagi sumber daya manusia rumah sakit, pasien, pendamping pasien, pengunjung, maupun lingkungan rumah sakit melalui upaya pencegahan kecelakan kerja dan penyakit akibat kerja di rumah sakit.Maka dari itu,penting bagi kita untuk mengetahui konsep dasar K3 dilingkungan rumahsakit antara lain adalah: sehat dan kesehatan kerja,risiko \& hazard dalam pemberian asuhan keperawatan. Dengan mengetahui sifat dan karakteristik bahaya, maka dapat lebihberhati-hati dan waspada untuk melakukan langkah-langkah pengamanan agar tidak terjadi kecelakaan,namun tidak semua bahaya dapat dikenali dengan mudah.

\section{G. DAFTAR PUSTAKA}

AFRIANTO, RIFKI.(2017).ANALISIS POTENSI BAHAYA SERTA KAJIAN RISIKO KESELAMATAN DAN KESEHATAN KERJA PROFESI RADIOGRAFER DI RUMAH SAKIT PELITA ANUGERAH MRANGGEN DEMAK. Undergraduate thesis, Universitas Muhammadiyah Semarang.

Azza Ivana, B. W. (2014). Analisa Komitmen Manajemen Rumah Sakit (RS) Terhadap Keselamatan Dan Kesehatan Kerja (K3) Pada RS Prima Medika Pemalang. JURNAL KESEHATAN MASYARAKAT, 2(1), 35-41.

Cindy Dwi Yuliandi, et.al. (2019). PENERAPAN KESELAMATAN DAN KESEHATAN KERJA (K3) DI LINGKUNGAN KERJA BALAI INSEMINASI BUATAN (BIB) LEMBANG. ejournal UPI,18(2), 98-109.

Dewi,Anita P.S.2018. DASAR-DASAR KESELAMATAN DAN KESEHATAN KERJA. Jember: Jember University Press.

HIDAYAH, WULAN FATWA (2019) ANALISIS FAKTOR RISIKO DAN HAZARD DALAM IMPLEMENTASI KEPERAWATAN. Bachelor thesis, UNIVERSITAS MUHAMMADIYAH PURWOKERTO.

M G Catur Yuant ari, et.al. (2018). Analisis Risiko Keselamatan dan Kesehatan Kerja Pada Petugas Kebersihan di Rumah Sakit . 107Faletehan Health Journal,5 (3), 107-116. 
NOVTIKASARI, RIA. (2017). HUBUNGAN KARAKTERISTIK PEKERJA, PENGGUNAAN APD DAN PENCAHAYAAN DENGAN KECELAKAAN KERJA(Studi di Unit Usaha Pengrajin Monel Desa Kriyan Kalinyamatan Jepara). Undergraduate thesis, Universitas Muhammadiyah Semarang.

Redjeki,Sri.2016.Kesehatan dan Keselamatan Kerja.Jakarta : Pusdik SDM Kesehatan.

Simamora, R. H. (2011). ROLE CONFLICT OF NURSE RELATIONSHIP WITH PERFORMANCE IN THE EMERGENCY UNIT OF HOSPITALS RSD DR. SOEBANDI JEMBER. The Malaysian Journal of Nursing, 3(2), 23-32.

Suci Oktavia Dwi Ningsih, et.al. (2019). ANALISIS RESIKO KESELAMATAN DAN KESEHATANKERJA (K3) DENGAN MENGGUNAKAN METODEHAZARDAND OPERABILITY STUDY (HAZOP) PADA BAGIANHYDROTEST MANUALDI PT. CLADTEK BI METALMANUFACTURING. Journal of BusinessAdministration,3(1), 29-39.

Triyono,Bruri,et.al.2014. BUKU AJAR KESELAMATAN DAN KESEHATAN KERJA (K3).Yogyakarta:UNYPRESS. 